\title{
Automated microparticle enzyme immunoassays for IgG and IgM antibodies to Toxoplasma gondii
}

\author{
J W Safford, G G Abbott, M C Craine, R G MacDonald
}

\begin{abstract}
Fully automated microparticle enzyme immunoassays (MEIA) for the IMx immunoassay analyser were developed to detect IgG and IgM antibodies to Toxoplasma gondii. The IgG MEIA results are expressed in International Units (IU) of IgG antibody interpolated from a six point calibration curve covering the range from 0 to $300 \mathrm{IU} / \mathrm{ml}$. Reproducible results were obtained from a calibration curve stored in the instrument for at least one month. The qualitative IgM MEIA expresses results as an index using a single calibrator included in each run. The Toxo IgG MEIA and Toxo IgM MEIA were in $98 \%$ and $97 \%$ agreement, respectively, with the reference assays used. Twenty four sera can be completely processed in about 35 minutes.
\end{abstract}

Infection with the obligate parasite Toxoplasma gondii is common throughout the world. Fortunately, most infections range from asymptomatic to mild symptoms. ${ }^{1}$ There are, however, several conditions in which acquired infection or reactivation of latent infections can be life threatening, such as pregnancy, after transplantation, and AIDS. Serological test results in each of these conditions, however, can provide important information for improved patient management.

Infection during pregnancy often results in fetal damage, causing a stillbirth or birth of an infant with congenital toxoplasmosis, the effects of which may not be apparent, for months or even years. ${ }^{2}$ Mandatory prenatal serological screening in France has shown that timely diagnosis by seroconversion, rising IgG antibody titres, or the presence of IgM antibody $^{3}$ followed by prenatal treatment can alleviate the effects of congenital toxoplasmosis. ${ }^{4} T$ gondii antibody negative, immunosuppressed recipients of heart, or heart and lung, transplants from antibody positive donors can acquire potentially fatal primary $T$ gondii infections. Serological test results can identify the susceptible patients, thus allowing appropriate treatment to be started. ${ }^{5}$ Reactivation of latent $T$ gondii infection in patients with AIDS is one of the most common causes of central nervous system complications in this group. ${ }^{6}$ Although serological test results are not reliable indicators of acute toxoplasmosis in patients with AIDS, ${ }^{6}$ the absence of IgG antibody may rule out a diagnosis of toxoplasma encephalitis. ${ }^{67}$
Increased awareness of the potentially devastating effects of toxoplasmosis and the possibility that serological screening will gain wider acceptance ${ }^{8}$ demand the availability of easily performed, accurate, and reliable serological assays. We report the development of two fully automated microparticle enzyme immunoassays (MEIA), performed on the IMx immunoassay analyser, ${ }^{9}$ for the detection of IgG and IgM antibodies to $T$ gondii.

TOXO IGG MEIA

Polystyrene microparticles are coated with antigens extracted from the $\mathrm{Rh}$ strain of $T$ gondii ${ }^{10}$ propagated in human foreskin cells. When incubated with a patient's serum, $T$ gondii specific antibody reacts with the antigen coated microparticle solid phase. The incubation mixture is transferred to a glass fibre matrix which captures the microparticles, allowing unbound serum components to be washed into a blotter located below the matrix. Affinity purified goat anti-human IgG (Kirkegaard and Perry, Gaithersburg, Maryland), coupled to alkaline phosphatase (Boehringer and Mannheim, Indianapolis, Indiana), followed by methylumbelliferyl phosphate (MUP) is used to detect the presence of IgG antibody bound to the $T$ gondii antigens on the solid phase. The rate of fluorescence development as MUP is dephosphorylated to methylumbelliferone is measured by the front-surface fluorometer within the IMx. ${ }^{9}$ The Toxo IgG MEIA is quantitative; results are interpolated from a six point calibration curve referenced to the World Health Organisation International Standard For anti-Toxoplasma serum. The six calibrators contain $0,10,50,75,150$ and $300 \mathrm{IU}$ IgG antibody/ml.

\section{Reproducibility of calibration curve after storage}

Calibration curve storage would avoid the necessity of running a complete set of calibrators in every run; therefore a reproducibility study was performed to determine if calibrator values could be stored within the software and used in subsequent runs. Two control sera and a four member panel were selected to represent each of the five line segments in the six point calibration curve. Calibrators, controls, and panels were tested nine times in duplicate over 35 days. To compensate for minor day to day variations, the stored calibration curve was normalised by an adjustment factor calculated for 
each run by dividing the value of a $50 \mathrm{IU} / \mathrm{ml}$ calibrator included in each run by the stored value of the $50 \mathrm{IU} / \mathrm{ml}$ calibrator. The $\mathrm{IU} / \mathrm{ml}$ of the controls and panels were calculated by point to point interpolation from the curve stored on the first day of the study after normalisation by multiplying the stored calibrator values by the adjustment factor. To determine if accurate adjustment could be obtained using only a single $50 \mathrm{IU} / \mathrm{ml}$ calibrator on each carousel, the adjustment factor was calculated using the first replicate of that calibrator instead of using the mean of duplicate values.

\section{Specificity and sensitivity}

Four hundred and twenty sera obtained from clinical laboratories in the United States and France were tested by the Toxo IgG MEIA. Results of less than $6 \mathrm{IU} / \mathrm{ml}$ were interpreted as negative and those of $6 \mathrm{IU} / \mathrm{ml}$ or greater as positive. The relative sensitivity and specificity of the MEIA were determined by comparison with results obtained with IgG specific reference assays.

The primary reference used in the comparative study was the enzyme immunoassay (EIA) Toxo-G EIA (Abbott Laboratories, North Chicago). The results of Toxo-G EIA were expressed as an index derived by dividing the test serum result by the result of the low positive control; results of less than 0.5 were interpreted as negative; results of 0.5 or greater were interpreted as positive. Discordant results between the Toxo IgG MEIA and Toxo-G EIA were resolved with the Enzygnost Toxoplasmosis/IgG assay (Behringwerke AG, Marburg, Germany).

TOXO IGM MICROPARTICLE ENZYME

IMMUNOASSAY

The Toxo IgM MEIA is similar to the IgG MEIA in many respects, but with three principal differences. First, IgM antibody to $T$ gondii was detected using affinity purified goat anti-human IgM (Kirkegaard and Perry, Gaithersburg, Maryland) coupled to alkaline phosphatase. Secondly, the results are qualitative and are expressed as an index derived by dividing the patient value by the value of an index calibrator included in each run. Finally, serum samples with an index of 0.5 or greater were adsorbed with microparticles coated with human gamma globulin (HGG) to remove rheumatoid factor. Samples with an index of less than 0.5 are regarded as negative without further testing. To adsorb the reactive samples, serum and microparticles were mixed and incubated at room temperature for five minutes, followed by five to 10 minutes centrifugation at $10000 \times \mathrm{g}$. The adsorbed supernatant was retested. Adsorbed sera with results of 0.6 and greater are positive for IgM antibody to $T$ gondii. Results of 0.5 to 0.599 are indeterminate for the presence of acute phase IgM antibody and results of less than 0.5 are regarded as negative.

\section{Reproducibility}

Inter- and intra-assay reproducibility were determined by performing 10 runs containing the index calibrator, a negative control, and two levels of positive sera in duplicate over 21 days. The index of each test sample was calculated by dividing the sample value by the value of a single replicate of the index calibrator.

\section{Sensitivity and specificity}

The effectiveness of the HGG coated microparticles in removing rheumatoid factor was tested by creating a series of rheumatoid factor positive sera containing increasing titres of IgG antibody to $T$ gondii in the absence of $\mathrm{IgM}$ anti$T$ gondii antibody. Dilutions of a serum highly positive for $\mathrm{IgG}$ antibody $(1500 \mathrm{IU} / \mathrm{ml})$ were made in a negative serum. One volume of each of the dilutions was mixed with three volumes of a rheumatoid factor positive serum (titre 1/ 1280 ) resulting in a series of sera containing from 1 to $269 \mathrm{IU} / \mathrm{ml} \mathrm{IgG}$ antibody to $T$ gondii in the presence of rheumatoid factor. Each of the sera were tested by both the Toxo IgG and Toxo IgM MEIA, as described previously.

Four hundred and ninety five sera obtained from clinical laboratories in the United States, France, Germany, Italy and Spain were tested by the Toxo IgM MEIA. Sera with an index of 0.5 or greater were treated to adsorb any rheumatoid factor and retested as described previously. Results from the IgM MEIA were compared with those obtained by the reference assay Toxo-M EIA (Abbott Laboratories, North Chicago). A Toxo-M EIA index of less than 0.4 is negative, an index of 0.5 or greater is positive, and the intermediate values $(0.4$ $0.499)$ are equivocal. Those sera giving discordant results between the MEIA and the reference EIA were tested by an immunosorbent agglutination assay (ISAGA) specific for IgM antibody to $T$ gondii (Toxo-ISAGA, bioMèrieux, France).

\section{IgG and IgM seroconversion}

Sera obtained from patients with serological evidence of primary exposure to $T$ gondii were tested by both the Toxo IgG MEIA and Toxo IgM MEIA. Sera and Sabin-Feldman dye test results ${ }^{11}$ were kindly supplied by Professor Thulliez, Institut de Puericulture de Paris, Laboratorie de Serologie Neonatale, Paris, France.

Inter- and intra-assay reproducibility were calculated by one way analysis of variance using Statgraphics software package (STSC, Inc, Rockville, Maryland).

\section{Results}

STORAGE REPRODUCIBILITY OF TOXO IGG MEIA CALIBRATION CURVE

A calibration curve was stored in the instrument software for a period of 35 days. During that time nine runs were performed containing duplicate calibrators, controls, and panel members. Consistent control and panel 
Table 1 Toxo IgG MEIA 35 day curve storage reproducibility

\begin{tabular}{|c|c|c|c|c|c|c|}
\hline \multirow[b]{2}{*}{ Test sample } & \multirow{2}{*}{$\begin{array}{l}\text { Number of } \\
\text { assays }\end{array}$} & \multirow{2}{*}{$\begin{array}{l}\text { Grand } \\
\text { mean } I U / m l\end{array}$} & \multicolumn{2}{|c|}{ Interassay } & \multicolumn{2}{|c|}{ Intra-assay } \\
\hline & & & $S D$ & $C V$ & $S D$ & CV \\
\hline $\begin{array}{l}\text { Negative control } \\
\text { Positive control } \\
\text { Panel 1 } \\
\text { Panel } 2 \\
\text { Panel } 3 \\
\text { Panel } 4\end{array}$ & $\begin{array}{l}9 \\
9 \\
9 \\
9 \\
9 \\
9\end{array}$ & $\begin{array}{r}0 \cdot 3 \\
95 \cdot 6 \\
8 \cdot 0 \\
32 \cdot 8 \\
68 \cdot 7 \\
218 \cdot 8\end{array}$ & $\begin{array}{r}6.1 \\
0.8 \\
1.6 \\
4.9 \\
26.4\end{array}$ & $\begin{array}{r}6 \% \\
10 \% \\
5 \% \\
7 \% \\
12 \%\end{array}$ & $\begin{array}{r}0.3 \\
0.3 \\
1.5 \\
2.6 \\
10.0\end{array}$ & $\begin{array}{l}3 \% \\
4 \% \\
4 \% \\
4 \% \\
5 \%\end{array}$ \\
\hline
\end{tabular}

*Negative control values less than $0 \mathrm{IU} / \mathrm{ml}$ were not extrapolated from the standard curve and were assigned a value of 0 . Analysis of variance was therefore not done

results were obtained over the 35 day period using the stored adjusted calibration curve, showing that a single calibration curve can be used for at least one month with adjustment by a single $50 \mathrm{IU} / \mathrm{ml}$ calibrator on each carousel (table 1). The excellent intra-assay reproducibility throughout the entire range of the calibration curve indicates that patient sera may be evaluated from a single replicate.

\section{TOXO IGG MEIA SENSITIVITY AND SPECIFICITY}

Two hundred and fifty out of the 420 sera tested with the reference Toxo-G EIA were negative by that assay. The 250 reference EIA negative sera were tested with the Toxo IgG MEIA. The results of the MEIA ranged from 0 to $15.5 \mathrm{IU} / \mathrm{ml}$ with a mean (SD) of $0.9(1.7)$ and a median of $0 \cdot 3$. Four $(1 \cdot 6 \%)$ of the reference EIA negative sera were greater than $6 \mathrm{IU} / \mathrm{ml}$ (range 6.6-15.5) by the MEIA.

The 170 reference EIA positive sera were tested with the Toxo IgG MEIA. Those results ranged from 3.5 to greater than $300 \mathrm{IU} / \mathrm{ml}$; the 164 results of less than $300 \mathrm{IU} / \mathrm{ml}$ had a mean (SD) of $39.5(45.6)$ and a median of $25 \cdot 7$. Six $(3.5 \%)$ of the reference EIA positive sera were less than $6 \mathrm{IU} / \mathrm{ml}$ (range 3.5-5.2) by the MEIA.

The 10 sera giving discordant results between the reference EIA and the Toxo IgG MEIA were tested with the Enzygnost EIA. The four reference EIA negative/MEIA positive sera were negative, and the six reference EIA positive/MEIA negative sera were positive by the Enzygnost EIA. Thus the relative specificity, sensitivity, and accuracy of the Toxo IgG MEIA is $98.4 \%(246 / 250)$, $96.5 \%(164 / 170)$, and $97.6 \%(410 / 420)$, respectively.

\section{REPRODUCIBILITY OF TOXO IGM MEIA}

Index calibrators and three samples were tested in duplicate in 10 runs over 21 days. Table 2 shows that consistent control and panel results were obtained. As with the Toxo IgG MEIA, the excellent Toxo IgM MEIA intra-assay reproducibility indicates that patient sera may be evaluated on the basis of a single replicate.
Table 221 day reproducibility of Toxo IgM MEIA

\begin{tabular}{|c|c|c|c|c|c|c|}
\hline \multirow[b]{2}{*}{ Test sample } & \multirow{2}{*}{$\begin{array}{l}\text { Number of } \\
\text { assays }\end{array}$} & \multirow{2}{*}{$\begin{array}{l}\text { Grand } \\
\text { mean index }\end{array}$} & \multicolumn{2}{|c|}{ Interassay } & \multicolumn{2}{|c|}{ Intra-assay } \\
\hline & & & $S D$ & $C V$ & $S D$ & $C V$ \\
\hline $\begin{array}{l}\text { Negative control } \\
\text { Positive control } \\
\text { Panel } 1\end{array}$ & $\begin{array}{l}10 \\
10 \\
10\end{array}$ & $\begin{array}{l}0.273 \\
1.524 \\
2 \cdot 694\end{array}$ & $\begin{array}{l}0.036 \\
0.079 \\
0.111\end{array}$ & $\begin{array}{r}13 \% \\
5 \% \\
4 \%\end{array}$ & $\begin{array}{l}0.037 \\
0.045 \\
0.091\end{array}$ & $\begin{array}{r}14 \% \\
3 \% \\
3 \%\end{array}$ \\
\hline
\end{tabular}

TOXO IGM SENSITIVITY AND SPECIFICITY

Test results from the series of anti- $T$ gondii IgM negative sera containing rheumatoid factor and increasing titres of IgG antibody to $T$ gondii are shown in table 3 . As expected, the binding of IgM rheumatoid factor to the microparticles increases considerably with increasing densities of bound IgG (rheumatoid factor IgM index) (table 3). Adsorption of the sera with an index of 0.5 or greater with HGG coated microparticles effectively removed rheumatoid factor and resulted in negative Toxo IgM indices (Toxo IgM index) (table 3). These results show that adsorption of sera with HGG coated microparticles is an effective method for avoiding false positive Toxo IgM results due to rheumatoid factor.

Four hundred and ninety five sera were tested by the Toxo IgM MEIA and the Toxo$M$ reference EIA. Results equivocal for clinically important titres of IgM antibody were obtained with both assays. The 47 sera with equivocal results (21 MEIA, 18 reference EIA, and eight equivocal by both assays) were excluded from determinations of specificity, sensitivity, and accuracy. A summary of the Toxo IgM MEIA and reference EIA results is shown in table 4.

Out of the remaining 448 sera, 364 were negative by the reference EIA. The MEIA results ranged from 0.092-1.998 with a mean (SD) of $0.292(0.167)$ and a median of 0.254 . Fourteen $(3.8 \%)$ of the reference EIA negative sera were greater than 0.600 (range 0.655 1.998 ) by the Toxo IgM MEIA. Eighty four sera were positive by the reference EIA. Toxo IgM MEIA results ranged from 0.238-4.769 with a mean (SD) of 1.565 (1) and a median of $1 \cdot 244$. Seven $(8 \cdot 3 \%)$ of the reference EIA positive sera were less than 0.6 (range 0.238 0.483 ) by the Toxo IgM MEIA.

Nineteen of the 21 sera giving discordant results between the reference EIA and the Toxo IgM EIA were tested by ISAGA (table 4). The seven reference EIA positive/MEIA negative sera were positive by ISAGA. Five negative and seven positive ISAGA results were obtained from the 14 reference EIA negative/MEIA positive sera (two were of insuffiicient volume for further testing). The seven ISAGA positive/EIA negative sera were removed from the group of 364 negative sera and considered positive for IgM antibody to $T$ gondii. Ultimately, this resulted in an IgM

Table 3 Rheumatoid factor and Toxo IgM MEIA results

\begin{tabular}{lll}
\hline Toxo IgG IU/ml & $\begin{array}{l}\text { Rheumatoid factor } \\
\text { IgM index }\end{array}$ & Toxo IgM index \\
\hline 1 & $0 \cdot 269$ & $0 \cdot 269$ \\
51 & $0 \cdot 363$ & $0 \cdot 363$ \\
63 & $0 \cdot 414$ & $0 \cdot 414$ \\
68 & $0 \cdot 514$ & $0 \cdot 228$ \\
71 & $0 \cdot 590$ & $0 \cdot 235$ \\
84 & $0 \cdot 626$ & $0 \cdot 261$ \\
86 & $0 \cdot 695$ & $0 \cdot 227$ \\
110 & 0.931 & $0 \cdot 223$ \\
131 & 0.997 & $0 \cdot 234$ \\
146 & 1.166 & $0 \cdot 244$ \\
175 & 1.485 & $0 \cdot 249$ \\
219 & $1 \cdot 896$ & $0 \cdot 284$ \\
269 & $2 \cdot 583$ & $0 \cdot 370$ \\
\hline
\end{tabular}


Table 4 Toxo IgM MEIA and reference $E I A$ results

\begin{tabular}{llllc}
\hline & \multirow{4}{l}{$\begin{array}{l}\text { Reference EIA } \\
\text { Number }\end{array}$} & Negative & Equivocal & Positive \\
\cline { 3 - 5 } IMx Toxo IgM MEIA & 364 & 350 & 7 & $7^{\star}$ \\
\hline Negative & 29 & 15 & 8 & 6 \\
Equivocal & 102 & $14 \dagger$ & 11 & 77 \\
Positive & 495 & 379 & 26 & 90 \\
Total & & &
\end{tabular}

*The seven sera were positive by ISAGA.

tFive of the 14 were ISAGA negative, seven were ISAGA positive, and two were of insufficient volume for ISAGA testing.

antibody negative group of 357 (364-7) sera and an antibody positive group of $91(84+7)$ sera. Thus the relative specificity, sensitivity, and accuracy of the Toxo IgM MEIA is $98.0 \%$ (350/357), 92.3\% (84/91), and 96.9\% (434/ 448), respectively.

\section{IGG AND IGM SEROCONVERSION}

Sera from 10 patients who had shown seroconversion from dye test negative to dye test positive were tested by both the Toxo IgG and IgM MEIA. In all cases IgG antibody seroconversion and $\mathrm{IgM}$ antibody were detected by the MEIA. These results, shown in table 5, indicate that serodiagnosis may be made with the Toxo IgG MEIA by testing paired sera from patients recently exposed to $T$ gondii.

\section{Discussion}

The instrumentation used for these assays precisely controls timing, temperature, and volume, ${ }^{9}$ resulting in reproducibility that is difficult to obtain with manual methods. Samples can therefore be tested without replication, six point calibration curves can be stored for at least one month using a single 50 $\mathrm{IU} / \mathrm{ml}$ calibrator on each carousel, and a single IgM calibrator, from which index values are calculated, can be used. Several checks are made by the software to assure that all assay variables are within specified ranges for each run. Total run times of about 35 minutes are achieved primarily by the large surface area provided by the microparticle solid phase. Test samples are exposed to about $20 \mathrm{~cm}^{2}$ of antigen

Table $5 \mathrm{IgG}$ and $\mathrm{IgM}$ seroconversion after exposure to $T$ gondii

\begin{tabular}{|c|c|c|c|c|}
\hline Case No & Date & Dye test titre & Toxo $\mathrm{IgG} \mathrm{IU} / \mathrm{ml}$ & Toxo IgM index \\
\hline 1 & $\begin{array}{l}22-M a r-89 \\
30-M a y-89\end{array}$ & $\begin{array}{l}<2 \\
400\end{array}$ & $\begin{array}{l}2 \\
6\end{array}$ & $\begin{array}{l}0.295 \\
1.971\end{array}$ \\
\hline \multirow[t]{2}{*}{2} & $\begin{array}{l}\text { 02-Dec-88 } \\
\text { 16-Jan-89 }\end{array}$ & $\begin{array}{r}<2 \\
5\end{array}$ & $\begin{array}{l}2 \\
3\end{array}$ & $\begin{array}{l}0.389 \\
0.494\end{array}$ \\
\hline & $10-F e b-89$ & 200 & 72 & $2 \cdot 282$ \\
\hline \multirow[t]{2}{*}{3} & 14-Mar-89 & $<2$ & 5 & $\begin{array}{l}0.404 \\
0.521\end{array}$ \\
\hline & $\begin{array}{l}\text { 28-Apr-89 } \\
\text { 19-May-89 }\end{array}$ & $\begin{array}{r}10 \\
100\end{array}$ & $\begin{array}{r}6 \\
51\end{array}$ & $\begin{array}{l}0.521 \\
0.854\end{array}$ \\
\hline \multirow[t]{2}{*}{4} & 16-Jan-89 & $<2$ & 3 & 0.493 \\
\hline & 07-Feb-89 & 100 & 9 & $2 \cdot 499$ \\
\hline \multirow[t]{2}{*}{5} & $04-F e b-89$ & $<2$ & 3 & 0.340 \\
\hline & 29-Apr-89 & 200 & 14 & $0 \cdot 704$ \\
\hline 6 & $\begin{array}{l}10-M a r-88 \\
19-A p r-88\end{array}$ & $\begin{array}{r}<2 \\
1600\end{array}$ & $\begin{array}{r}3 \\
>300\end{array}$ & $\begin{array}{l}0.398 \\
2.893\end{array}$ \\
\hline \multirow[t]{2}{*}{7} & $21-$ Nov-88 & $<2$ & 1 & 0.314 \\
\hline & $\begin{array}{l}\text { 22-Dec-88 } \\
04-\operatorname{Tan}-89\end{array}$ & $\begin{array}{r}20 \\
160\end{array}$ & $\begin{array}{r}8 \\
33\end{array}$ & $\begin{array}{l}0.755 \\
0.785\end{array}$ \\
\hline \multirow{2}{*}{8} & 09-Aug-88 & $<2$ & $\begin{array}{r}33 \\
2\end{array}$ & $\begin{array}{l}0.785 \\
0.336\end{array}$ \\
\hline & $27-$ Sep-88 & 800 & 7 & $2 \cdot 287$ \\
\hline \multirow[t]{2}{*}{9} & 28-Apr-89 & $<2$ & 4 & 0.404 \\
\hline & 26-Jun-89 & 100 & 25 & 1.699 \\
\hline \multirow[t]{3}{*}{10} & 22-May-89 & $<2$ & 2 & 0.373 \\
\hline & 08-Jun-89 & 80 & 5 & $0 \cdot 696$ \\
\hline & 22-Jun-89 & 800 & 31 & 3.312 \\
\hline
\end{tabular}

coated solid phase, permitting incubation times of only nine (IgG assay) or 10 (IgM assay) minutes. When transferred to the glass fibre matrix, the microparticles are captured by the fibre surfaces allowing unbound components to be washed into the blotter. The relatively open matrix of fibres results in more efficient sample flow than would membranes containing submicron pores.

For sera which were initially reactive in the IgM MEIA it was necessary to add one manual procedure to the assay to ensure that false positive results were not obtained when testing samples positive for IgM rheumatoid factor and IgG anti- $T$ gondii antibodies. It is critical to neutralise rheumatoid factor in $\operatorname{IgM}$ antibody assays whether they use antigen coated solid phase (indirect) or anti-IgM antibody capture (direct) methods as both are susceptible to this problem. ${ }^{1213}$ Results reported here show that adsorption with HGG coated microparticles effectively neutralises rheumatoid factor interference.

The results of rapid, automated MEIA IgG and IgM assays described here compare favourably with manual methods $(97.6 \%$ and $96.9 \%$ overall agreement, respectively). The few discordant results are to be expected when comparing assays of such diverse technologies as MEIA, $6.4 \mathrm{~mm}$ polystyrene bead EIA, microtitre EIA and agglutination of tachyzoites using anti-IgM coated microtitre wells. There is no universally accepted standard of antibody activity with which the sensitivity of IgG and IgM anti- $T$ gondii assays can be calibrated. The cut off values for both Toxo IgG and IgM MEIAs were determined by analysis of the distributions of results from negative and positive populations of sera.

The type of $T$ gondii antigen preparation used in assays may also influence results. Outer membrane proteins of $T$ gondii are important factors in the detection of antibodies appearing in the acute stage of infection. ${ }^{14}$ Antigens on the MEIA microparticles were extracted from both tachyzoites and infected host cells. The latter develop intravacuolar networks containing the major outer membrane proteins of $T$ gondii. ${ }^{15}$ The dominant outer membrane protein P30 has also been found in both intracellular and extracellular vesicles. ${ }^{16}$ Thus $T$ gondii antigens prepared from both extracellular tachyzoites and infected cells may be enriched in the major outer membrane proteins permitting the detection of early acute phase antibodies. The concurrent detection of seroconversion by both the IgG MEIA and the dye test suggests that the MEIA detects IgG antibody appearing early after infection. The dates of infection, however, were not available for the sera used in the seroconversion study reported here. Other studies have shown that the IgG MEIA does detect acute phase antibody appearing 15 to 45 days after infection ( $T$ Kien, personal communication). The ability of an IgG assay to detect seroconversion during the early acute phase of infection could be crucial in differentiating acute phase IgM antibody from residual IgM antibody in convalescent sera. 
The results reported here show that the IMx immunoassay analyser and the Toxo MEIA IgG and IgM antibody assays offer accurate, rapid, fully automated alternatives to manual immunoassays. MEIA technology has also been successfully applied to rubella IgG and IgM assays ${ }^{17}$ and has the potential for including immune response screening and serodiagnostic assays for other infectious diseases as well. We gratefully acknowledge the expert assistance of Dr M Perlin, provided the large quantities of $T$ gondii required for this study.

1 Remington JS. Toxoplasmosis in the adult. Bull NY Acad Med 1974.50.211-27.

2 Alford CA, Stagno S, Reynolds DW. Toxoplasmosis: Silent congenital infection. In: Krugman $\mathrm{S}$, Gerson $\mathrm{AE}$, eds. Infections of the fetus and the newborn infant. New York: Alan R Liss, 1975:133-57.

3 Desmonts G, Forestier F, Thulleiz PH, Dafford F, CapellaPavlosky M, Chartier M. Prenatal diagnosis of congenital toxoplasmosis. Lancet 1985;i:500-4.

4 Daffos FD, Forestier F, Capella-Pavlosky M, et al. Prenatal management of 749 pregnancies at risk for congenital toxoplasmosis. $N$ Engl J Med 1988;318:271-5.

5 Wreghitt TG, Hakim M, Gray JJ, et al. Toxoplasmosis in heart and heart and lung transplant recipients. J Clin Pathol 1989;42:194-9.

6 Levy RM, Bredesen DE, Rosenblum ML. Neurological manifestations of the acquired immunodeficiency syn- drome (AIDS): Experience at UCFS and review of the literature. $J$ Neurosurg 1985;62:475-95.

7 Cohn JA, McMeeking A, Cohen W, Jacobs J, Holtzman RS. Evaluation of the policy of empiric treatment of suspected Toxoplasma encephalitis in patients with the acquired Toxoplasma encephalitis in patients with the acquired
immunodeficiency syndrome. Am J Med 1989;86:521-7.

8 McCabe R, Remington JS. Toxoplasmosis: The time has come. N Engl J Med 1988;318:313-15.

9 Fiore $M$, Mitchel J, Doan $T$, et al. The Abbott IMx automated benchtop immunochemistry analyzer system. Clin Chem 1988;34:1726-32.

10 Sabin AB. Toxoplasmic encephalitis in children. JAMA 1941;116:801-7.

11 Sabin AB, Feldman HA. Dyes as microchemical indicators of a new immunity phenomenon affecting a protozoan parasitc (Toxoplasma). Science 1948;108:660-3.

12 Meurman $\mathrm{OH}$, Zioloa BR. IgM-class rheumatoid factor interference in the solid-phase radioimmunoassay of rubella-specific IgM antibodies. J Clin Pathol 1978; 31:483-7.

13 Forghani B, Myoraku CK, Schmidt NJ. Use of monoclonal antibodies to human immunoglobulin $M$ in "capture" antibodies to human immunoglobulin $M$ in " capture"
assays for measles and rubella immunoglobulin M. J Clin Microbiol 1983;18:652-7.

14 Suzuki Y, Thulliez P, Desmonts G, Remington JS. Antigen(s) responsible for immunoglobulin $G$ response specific for the acute stage of Toxoplasma infection in humans. J Clin Microbiol 1988;26:901-5.

15 Sibley LD, Krahenbuhl JL. Modification of host cell phagosomes by Toxoplasma gondii involves redistribution of surface proteins and secretion of a $32 \mathrm{kDa}$ protein. Eur J Cell Biol 1988;47:81-7.

16 Dubremetz JF, Rodriguez C, Ferreira E. Toxoplasma gondii: Redistribution of monoclonal antibodies on tachyzoites during host cell invasion. Exp Parisitol 1985; 59:24-32.

17 Abbott GG, Safford JW, MacDonald RG, Craine MC Applegren RR. Development of automated immunoassays for immune status screening and serodiagnosis of assays for immune status screening and serodiagnosis of
rubella virus infection. J Virol Methods 1990;27:227-40. 